\title{
The Effect of Homogenization and Milk Fat Fractions on the Functionality of Mozzarella Cheese
}

\author{
M. K. Rowney, ${ }^{\star, 1}$ M. W. Hickey, ${ }^{\star}$ P. Roupas, $†$, and D. W. Everettł \\ *Institute of Land and Food Resources, University of Melbourne, Victoria 3052 Australia \\ †Food Science Australia, Werribee, Victoria 3030 Australia \\ $\ddagger$ Department of Food Science, University of Otago, Dunedin 9001 New Zealand
}

\section{ABSTRACT}

Mozzarella cheese was manufactured from milk containing either a low (olein) or a high (stearin) melting point fraction of milk fat or anhydrous milk fat. The fat was dispersed into skim milk by homogenization at 2.6 MPa before being manufactured into cheese. The melting point of the milk fat did not affect the size or shape of the fat globules, nor was there any effect of homogenization on the polymorphic state of the milk fat. There were no changes in milk fat globule size and shape concomitant with the amount of free oil formed. The polymorphic state of the milk fat did affect the amount of free oil formed and the apparent viscosity of the cheese. The lower melting point fraction yielded a larger amount of free oil. The higher melting point fraction yielded a higher viscosity of melted cheese at $60^{\circ} \mathrm{C}$. Mozzarella cheese was also manufactured from homogenized milk, nonhomogenized milk, and a 1:1 ratio of the two, without altering the milk fat composition. Increasing the proportion of homogenized milk yielded a lower free oil content and higher viscosity of the cheese.

(Key words: homogenization, mozzarella, free oil, fat globule)

Abbreviation key: AMF = anhydrous milk fat, CLSM $=$ confocal laser scanning microscopy, $\mathbf{D S C}=$ differential scanning calorimetry.

\section{INTRODUCTION}

The melting temperature of milk fat is a function of the crystalline state; $\alpha$ crystals melt below $20^{\circ} \mathrm{C}, \beta^{\prime}$ between 20 and $30^{\circ} \mathrm{C}$, and $\beta$ crystals above $30^{\circ} \mathrm{C}$ (Walstra and Jenness, 1984). The types of crystals formed are dependent on the rate of crystallization of the milk fat and triglyceride composition, each of which can vary

\footnotetext{
Received September 9, 2002.

Accepted October 9, 2002.

Corresponding author: D. W. Everett; e-mail: d.everett@ otago.ac.nz.

${ }^{1}$ Current address: Murray Goulburn Cooperative Co. Ltd., 140 Dawson St., Brunswick, Victoria, Australia.
}

with cow nutrition, genetics, and stage of lactation (Walstra and Jenness, 1984). Alteration of the relative ratios of each type of crystal will change the solid-to-liquid milk fat ratio, and this may have some impact upon the melting characteristics of cheese made from modified milk.

Previous studies exploring the role of milk fat on the functionality of Mozzarella cheese have changed the milk fat globule characteristics by homogenization of cheesemilk (Lelievre et al., 1990; Rudan et al., 1998), or indirectly by addition of emulsifying salts (Tunick et al., 1989). A reduction in the size of milk fat globules in cheesemilk has been directly associated with a decrease in free oil formation, and this is related to the fat-water interfacial membrane and the emulsion stability of the globule (Oberg et al., 1993; Cano-Ruiz and Richter, 1997). Measurement of the size and shape of fat globules in cheese is necessary to determine the impact on cheese functionality. Most microscopic approaches do not enable a direct assessment of the impact of the cheese-making process on the milk fat globule due to limitations in these techniques, which usually require removal of the fat during the preparation of the sample for analysis (Metzger and Mistry, 1995; Rudan et al., 1998; McMahon et al., 1999). However, confocal laser scanning microscopy (CLSM) provides an opportunity to observe and measure milk fat globules in cheese without disturbing the structure excessively (Blonk and van Aalst, 1993; Guinee et al., 1999).

Differential scanning calorimetry (DSC) is a useful tool for examining the melting point profile of milk fat in cheese. It has been used to distinguish between Mozzarella cheese made from bovine milk and that made from water buffalo milk (Tunick and Malin, 1997). Calcium caseinate is believed to affect the crystallization of milk fat in cheese, presumably when adsorbed at the fat globule-water interface, and this has been detected using DSC (Tunick et al., 1989). Measurement of enthalpy changes in Cheddar, American, and Mozzarella cheese by DSC, however, has had little success as a predictive tool to measure meltability (Park et al., 1984).

In the present study, DSC and CLSM were employed to measure milk fat polymorphic structure and globule 
size and shape as a consequence of 1 ) changing the melting profile of milk fat, and 2) homogenization of cheese milk without altering the fat composition. The effect of polymorphic structure and globule size and shape on free oil formation and apparent viscosity of Mozzarella cheese were examined.

\section{MATERIALS AND METHODS}

\section{Fractionated Milk Fat}

Anhydrous milk fat (AMF) was obtained from Food Science Australia (Werribee, Victoria, Australia) and separated to yield a low melting point fraction (olein) and a high melting point fraction (stearin) using a dry fractionation process (Tirtiaux, Fleurus, Belgium) (Versteeg et al., 1994).

\section{Cheese Milk Preparation}

Raw milk was obtained from a commercial manufacturer in Victoria, Australia, separated, stored overnight at $4^{\circ} \mathrm{C}$ and pasteurized at $73^{\circ} \mathrm{C}$ for $15 \mathrm{~s}$ on the day of manufacture of the cheese. Olein, stearin, and AMF were held at $50^{\circ} \mathrm{C}$ for $30 \mathrm{~min}$ and added to individual $200-\mathrm{L}$ portions of skim milk to give a protein to fat ratio of 1.4:1. The mixture was homogenized at $2.6 \mathrm{MPa}$ and $50^{\circ} \mathrm{C}$ to disperse the milk fat into the cheese milk. This experiment was conducted twice on successive days.

\section{Homogenized Cheese Milk}

The effect of fat globule size and shape on free oil formation was examined. Three treatments were prepared, pasteurized and homogenized milk at $2.6 \mathrm{MPa}$ and $50^{\circ} \mathrm{C}(200 \mathrm{~L}$, treatment 1$)$, pasteurized and nonhomogenized milk (200 L, treatment 2), and $100 \mathrm{~L}$ each of treatments 1 and 2 mixed in a 1:1 ratio (treatment 3 ). This experiment was conducted three times on successive days.

\section{Cheese Manufacture}

Bulk starter cultures (Streptococcus thermophilus and Lactobacillus delbrueckii ssp. bulgaricus, \#372 and \#474, Australian Starter Culture Research Center, Werribee, Victoria, Australia, 1.5\% wt/vol) were added to cheese milk at $39^{\circ} \mathrm{C}$. After $40 \mathrm{~min}$ of ripening at $39^{\circ} \mathrm{C}$, the milk was coagulated with chymosin (Chymogen, Chr. Hansen, Bayswater, Victoria, Australia). The coagulum was cut into $13-\mathrm{mm}$ cubes and held at $39^{\circ} \mathrm{C}$ until a whey $\mathrm{pH}$ of 6.1 was obtained, and then the whey was drained. The curd was milled, salted (1.5\% wt/wt), and stretched using a horizontal, single auger pilot-scale Mozzarella cooker-stretcher (Johnson and Nelles, Windsor, WI), con- taining brine solution $\left(3 \% \mathrm{NaCl}\right.$, wt/vol) at $65^{\circ} \mathrm{C}$, with a screw speed of $12 \mathrm{rpm}$ and a curd feed rate of $1.0 \mathrm{~kg} /$ min. Cheese cylinders ( $1 \mathrm{~kg}, 10-\mathrm{cm}$ diameter) were cooled for $60 \mathrm{~min}$ in iced water, vacuum packed in plastic barrier bags (Cryovac, Hamilton, New Zealand), and stored at $4^{\circ} \mathrm{C}$. Three days after manufacture, cheese was taken from refrigerated storage for apparent viscosity, free oil, CLSM, DSC, and compositional analyses.

\section{Compositional Analysis and Free Oil}

Curd was cut into 2-cm cubes, mixed, and shredded using a food processor (Moulinex, Paris, France). The moisture, fat, and protein contents were determined using near infrared spectroscopy (Infralab, TM5000E, Infrared Engineering, Irwindale, CA). Calibration curves were composed for Mozzarella cheeses encompassing a wide range of moisture, fat, and protein contents, and used to determine the composition of the experimental curd samples. A reference sample was used with each measurement. Analysis of the protein (as nitrogen) and fat content of the reference and calibration samples was done by standard techniques (International Dairy Federation, 1993, 1996). The moisture contents of the reference and calibration samples were determined gravimetrically at $105^{\circ} \mathrm{C}$ for $16 \mathrm{~h}$ in duplicate. The free oil content was measured by heating $9 \mathrm{~g}$ of shredded curd in a Babcock flask (Kindstedt and Rippe, 1990) and expressed as a percentage of total fat and of total curd weight.

\section{Polymorphic Structure}

The polymorphic structure of the milk fat was analyzed using a DSC (model DSC 7, Perkin Elmer, Shelton, CT) by measuring the energy required to melt fat crystals $\left(\alpha, \beta^{\prime}\right.$, and $\beta$ ). Cheese (15 to $30 \mathrm{mg}$ ) was accurately weighed into an aluminum DSC sample pan at $5^{\circ} \mathrm{C}$ and crimp sealed. The cheese was tempered at $5^{\circ} \mathrm{C}$ for $5 \mathrm{~min}$, heated to $50^{\circ} \mathrm{C}$ at $10^{\circ} \mathrm{C}$ per min, and the thermogram (heat flow in $\mathrm{mW}$ vs. temperature) recorded. The proportion of the area under the DSC thermogram was calculated below $20^{\circ} \mathrm{C}$, between 20 and $30^{\circ} \mathrm{C}$, and above $30^{\circ} \mathrm{C}$, and designated as the relative proportion of $\alpha, \beta^{\prime}$, and $\beta$ crystals, respectively.

\section{Apparent Viscosity}

Shredded cheese ( $80 \mathrm{~g})$ was placed into an open top glass cylinder of $48 \mathrm{~mm}$ diameter. The cheese was tempered for $20 \mathrm{~min}$ at $60^{\circ} \mathrm{C}$, then $10 \mathrm{ml}$ of $\mathrm{AMF}$ at $40^{\circ} \mathrm{C}$ was poured on top of the melted cheese to prevent drying. A T-bar spindle was mounted on a Brookfield digital viscometer (model RVTDA-II, Brookfield Engineering 
Labs Inc., Middleboro, MA) and lowered into the cheese until it was positioned $2 \mathrm{~cm}$ from the bottom of the cylinder. The cheese was tempered for an additional $20 \mathrm{~min}$ at $60^{\circ} \mathrm{C}$. The viscometer $(1 \mathrm{rpm})$ and helipath $(2.2 \mathrm{~cm} /$ min) were simultaneously activated and the percent yield recorded. The maximum peak height was used to determine the apparent viscosity (Kindstedt and Kiely, 1992). The percent yield was converted into apparent viscosity $(\mathrm{kPa})$ using conversion factors for each individual T-bar spindle.

\section{Milk Fat Globule Microstructure}

A thin slice $(10 \times 10 \mathrm{~mm})$ of approximately $1 \mathrm{~mm}$ thickness was cut from the curd at $4^{\circ} \mathrm{C}$ for microstructural analysis using CLSM (Rowney et al., 2003). The samples were stained using water-soluble rhodamine B fluorescent dye and lipid-soluble Nile Blue fluorescent dye (Sigma Chemical Co., St. Louis, MO). The confocal microscope (Leica, Heidelberg, Germany) employed an argon/krypton laser in dual-beam fluorescent mode, with excitation wavelengths of 647 and $568 \mathrm{~nm}$ for fat and aqueous phase, respectively. The fat globule size, shape, and location in the curd structure were determined from the microscope images using Image Tool for Windows version 2.0 (University of Texas Health Science Center, San Antonio, TX). The maximum cross-sectional diame- ter, cross-sectional area, and elongation (equal to the maximum diameter divided by the minimum cross-sectional diameter) were reported as number-weighted mean values (Everett and Olson, 2003).

\section{Statistical Analysis}

A randomized block design was used to evaluate the effect of the treatments on the dependent variables using SPSS 8.0 for Windows (SPSS Inc., Chicago, IL). Statistical significance was determined at $P<0.05$. Bonferroni comparisons were used to analyze the differences between means.

\section{RESULTS AND DISCUSSION}

\section{Cheese Composition}

The melting profile of milk fat in Mozzarella cheese, containing either olein, stearin, or AMF had no significant effect on the gross composition of cheese (Table 1). In contrast, homogenization of cheese milk resulted in significant differences in the composition of cheese (Table 2). An increase in the proportion of homogenized milk yielded a higher moisture content $(P<0.001)$ with a corresponding decrease in the protein content $(P<0.01)$. There was also an increase $(P<0.01)$ in the fat in dry matter as a result of homogenization, most likely due to

Table 1. Composition, free oil, apparent viscosity, melting properties, and fat globule structure of Mozzarella cheeses made from recombined milk containing anhydrous milk fat, the olein fraction, or the stearin fraction of milk fat $(n=2)$.

\begin{tabular}{|c|c|c|c|c|}
\hline & $\mathrm{AMF}$ & Olein & Stearin & Significance \\
\hline Moisture, \% & 45.3 & 46.0 & 45.5 & NS \\
\hline Fat, $\%$ & 24.3 & 23.7 & 24.0 & NS \\
\hline Fat in dry matter, $\%$ & 44.5 & 43.8 & 43.9 & NS \\
\hline Protein, \% & 25.8 & 25.1 & 26.7 & NS \\
\hline Salt, $\%$ & 1.6 & 1.7 & 1.7 & NS \\
\hline Salt in moisture, \% & 3.6 & 3.6 & 3.7 & NS \\
\hline Free oil, \% of cheese & $1.6^{\mathrm{a}}$ & $1.9^{\mathrm{b}}$ & $1.2^{\mathrm{c}}$ & $* * *$ \\
\hline Free oil, $\%$ of fat & $6.9^{\mathrm{a}}$ & $7.9^{\mathrm{b}}$ & $5.2^{\mathrm{c}}$ & $* * *$ \\
\hline Apparent viscosity, MPa.s & $0.83^{\mathrm{a}}$ & $0.99^{a}$ & $1.30^{\mathrm{b}}$ & $*$ \\
\hline Melting point, ${ }^{\circ} \mathrm{C}$ & $29.5^{\mathrm{a}}$ & $27.0^{\mathrm{b}}$ & $43.2^{\mathrm{c}}$ & $* * *$ \\
\hline Total energy under $\mathrm{DSC}^{1}$ curve, $\mathrm{J} / \mathrm{g}$ & $13.6^{\mathrm{a}}$ & $9.1^{\mathrm{b}}$ & $21.8^{\mathrm{c}}$ & $* * *$ \\
\hline$\alpha$ crystals $^{2}$ & $36.3^{\mathrm{a}}$ & $69.4^{\mathrm{b}}$ & $18.6^{\mathrm{c}}$ & $* * *$ \\
\hline$\beta^{\prime}$ crystals $^{3}$ & $63.4^{\mathrm{a}}$ & $29.8^{\mathrm{b}}$ & $33.4^{\mathrm{c}}$ & $* * *$ \\
\hline$\beta$ crystals $^{4}$ & $0.0^{\mathrm{a}}$ & $0.0^{\mathrm{a}}$ & $48.0^{\mathrm{b}}$ & $* * *$ \\
\hline Cross-sectional area, $\mu \mathrm{m}^{2}$ & 8.7 & 9.1 & 7.9 & NS \\
\hline Maximum diameter, $\mu \mathrm{m}$ & 3.5 & 3.4 & 3.1 & NS \\
\hline Elongation factor ${ }^{5}$ & 1.7 & 1.4 & 1.4 & NS \\
\hline
\end{tabular}

${ }^{\mathrm{a}, \mathrm{b}, \mathrm{c}}$ Subcolumn means within row and treatment category with different superscripts $\operatorname{differ}(P<0.05)$.

${ }^{1}$ Differential scanning calorimetry.

${ }^{2}$ Percentage of thermogram area below $20^{\circ} \mathrm{C}$.

${ }^{3}$ Percentage of thermogram area between 20 and $30^{\circ} \mathrm{C}$.

${ }^{4}$ Percentage of thermogram area above $30^{\circ} \mathrm{C}$.

${ }^{5}$ Elongation factor $=($ maximum diameter $) /($ minimum diameter $)$.

$* P<0.05$.

$* * * P<0.001$. 
Table 2. The effect of homogenization on the composition, free oil, apparent viscosity, melting properties, and fat globule structure of Mozzarella cheese $(n=3)$.

\begin{tabular}{|c|c|c|c|c|}
\hline & Treatment $1^{1}$ & Treatment $2^{2}$ & Treatment $3^{3}$ & Significance \\
\hline Moisture, \% & $51.5^{\mathrm{a}}$ & $45.8^{b}$ & $49.6^{\mathrm{c}}$ & $* * *$ \\
\hline Fat, $\%$ & $23.1^{\mathrm{a}}$ & $24.8^{\mathrm{b}}$ & $23.7^{\mathrm{c}}$ & $* * *$ \\
\hline Fat in dry matter, $\%$ & $47.6^{\mathrm{a}}$ & $45.8^{\mathrm{b}}$ & $47.0^{\mathrm{a}}$ & $* *$ \\
\hline Protein, \% & $20.2^{\mathrm{a}}$ & $23.7^{\mathrm{b}}$ & $21.6^{\mathrm{a}}$ & $* *$ \\
\hline Salt, $\%$ & $1.7^{\mathrm{a}}$ & $1.4^{\mathrm{b}}$ & $1.5^{\mathrm{c}}$ & $* *$ \\
\hline Salt in moisture, \% & 3.2 & 3.0 & 3.0 & NS \\
\hline Free oil, $\%$ of cheese & $2.7^{\mathrm{a}}$ & $9.0^{\mathrm{b}}$ & $5.5^{\mathrm{c}}$ & $* *$ \\
\hline Free oil, $\%$ of fat & $11.7^{\mathrm{a}}$ & $37.8^{\mathrm{b}}$ & $23.5^{\mathrm{c}}$ & $* *$ \\
\hline Apparent viscosity, MPa.s & $0.79^{\mathrm{a}}$ & $0.44^{\mathrm{b}}$ & $0.57^{\mathrm{c}}$ & $*$ \\
\hline Melting point, ${ }^{\circ} \mathrm{C}$ & 37.5 & 38.0 & 38.6 & NS \\
\hline Total energy under $\mathrm{DSC}^{4}$ curve, $\mathrm{J} / \mathrm{g}$ & 14.2 & 14.4 & 13.9 & NS \\
\hline$\alpha$ crystals $^{5}$ & 35.0 & 37.5 & 33.0 & NS \\
\hline$\beta^{\prime}$ crystals $^{6}$ & 14.0 & 15.2 & 16.8 & NS \\
\hline$\beta$ crystals $^{7}$ & 50.8 & 46.8 & 50.0 & NS \\
\hline Cross-sectional area, $\mu \mathrm{m}^{2}$ & $8.8^{\mathrm{a}}$ & $23.3^{\mathrm{b}}$ & $10.9^{c}$ & $* * *$ \\
\hline Maximum diameter, $\mu \mathrm{m}$ & $3.9^{\mathrm{a}}$ & $4.9^{\mathrm{b}}$ & $4.3^{\mathrm{a}}$ & $*$ \\
\hline Elongation factor ${ }^{8}$ & 1.6 & 1.9 & 2.1 & NS \\
\hline \multirow{2}{*}{\multicolumn{5}{|c|}{$\begin{array}{l}\text { a,b,c Subcolumn means within row and treatment category with different superscripts differ }(P<0.05) \text {. } \\
{ }^{1} \text { Treatment } 1 \text { contains homogenized milk. }\end{array}$}} \\
\hline & & & & \\
\hline \multicolumn{5}{|c|}{${ }^{2}$ Treatment 2 contains nonhomogenized milk. } \\
\hline \multicolumn{5}{|c|}{${ }^{3}$ Treatment 3 contains a 1:1 mixture of homogenized and nonhomogenized milk. } \\
\hline \multicolumn{5}{|c|}{${ }^{4}$ Differential scanning calorimetry. } \\
\hline \multicolumn{5}{|c|}{${ }^{5}$ Percentage of thermogram area below $20^{\circ} \mathrm{C}$. } \\
\hline \multicolumn{5}{|c|}{${ }^{6}$ Percentage of thermogram area between 20 and $30^{\circ} \mathrm{C}$. } \\
\hline \multicolumn{5}{|c|}{${ }^{7}$ Percentage of thermogram area above $30^{\circ} \mathrm{C}$} \\
\hline \multicolumn{5}{|c|}{${ }^{8}$ Elongation factor $=($ maximum diameter $) /($ minimum diameter $)}$. \\
\hline \multicolumn{5}{|c|}{$* P<0.05$} \\
\hline \multicolumn{5}{|l|}{$* * P<0.01$} \\
\hline$* * * P<0.001$ & & & & \\
\hline
\end{tabular}

lower fat losses into the stretching water and whey, which were not measured in this experiment.

\section{Free Oil and Viscosity of Mozzarella Cheese}

Given that the amount of free oil increases at higher cheese fat levels (Tunick, 1994), the free oil content was measured as a proportion of both the fat and the total cheese on a weight basis. The melting profile of fat in Mozzarella cheese had a significant effect on free oil formation and apparent viscosity (Table 1). Cheese made with the olein fraction had a higher $(P<0.001)$ free oil than the cheese made with the AMF fraction, which was higher $(P<0.001)$ than for the cheese containing the stearin fraction. Cheese made with the stearin fraction had a higher $(P<0.05)$ apparent viscosity than cheese made with the olein fraction or AMF. The solid-to-liquid milk fat ratio appears to affect the free oil content and apparent viscosity of Mozzarella cheese. Higher melting point fat would be less likely to melt and form pools of fat that subsequently leak out of the protein matrix of cheese to form free oil. A higher proportion of crystalline fat contributed to an increase of the modulus of deformability of unheated Cheddar cheese between 91 and 210 $\mathrm{d}$ of maturation (Watkinson et al., 1997); however, it is not clear if the mechanism behind this result can be extrapolated to Mozzarella cheese at $60^{\circ} \mathrm{C}$. If some of the fat globules destabilize after heating the Mozzarella cheese and form pools of fat encapsulated within the protein network, this undoubtedly would contribute to the viscosity of the cheese. The higher melting point fat would add more to viscosity than the lower melting point fraction. Conceivably, there would be no melting point fraction effect if the fat globules remained completely emulsified and did not at least partially leak out into the protein matrix.

Free oil formation was less $(P<0.01)$ in cheese made from homogenized milk than in cheese made with the 1:1 mixture, which was in turn less $(P<0.01)$ than cheese made from nonhomogenized milk (Table 2). There was an increase $(P<0.05)$ in the apparent viscosity of Mozzarella cheese as the proportion of homogenized milk increased (Table 2).

The results show that homogenization of the cheese milk yielded a reduction in free oil and an increase in the apparent viscosity of cheese. Homogenized milk contains smaller-sized milk fat globules partially coated with caseins to stabilize the expanded fat globule surface area (Sharma and Dalgleish, 1993). This may be responsible in part for the reduction in free oil and the increase in 
apparent viscosity observed when the cheese milk was homogenized. The caseins adsorbed onto the fat globule surface after homogenization may be able to form protein-protein bonds with the cheese casein matrix (CanoRuiz and Richter, 1997), thus increasing the rigidity of the cheese protein matrix. This will increase apparent viscosity and prevent oil from leaking from the protein matrix. It has been reported that a reduction in the size of milk fat globules by homogenization results in a decrease in free oil (Lelievre et al., 1990). Smaller, homogenized milk fat globules may also result in less disruption of the casein matrix, creating a more rigid protein structure that is better able to trap free oil.

Free oil of cheese that contains homogenized milk fat fractions plus skim milk (Table 1) may be lower than for cheese containing milk that was simply homogenized without altering the fat composition (Table 2). Although no direct comparisons can be made in this present study, as the experiments were independent, it has been reported that buttermilk that contains milk fat membrane material (which would have been absent at the fat-water interface after dispersing milk fat fractions into skim milk in this present study) results in significantly lower free oil formation and decreased cheese meltability (Poduval and Mistry, 1999).

\section{Polymorphic State of Milk Fat in Mozzarella Cheese}

The polymorphic structure of the milk fat in cheese was affected by the type of fat dispersed into the cheese milk (Table 1). The milk fat in the cheese made with olein had more $\alpha$ crystals than either of the other two cheeses $(P<0.001)$. Cheese made with AMF contained predominantly $\beta^{\prime}$ crystals, whereas cheese made with the stearin fraction contained predominantly $\beta$ crystals (Table 1). The melting profile of the fat in the three types of cheese is shown in the differential scanning calorimetry curves (Figure 1). The differences in free oil observed in the cheeses made with the milk fractions and AMF (Table 1) may be in part due to the differences in polymorphic state, as $\alpha$ crystals melt at approximately $20^{\circ} \mathrm{C}, \beta^{\prime}$ crystals between 20 and $30^{\circ} \mathrm{C}$, and $\beta$ crystals above $30^{\circ} \mathrm{C}$ (Walstra and Jenness, 1984). The higher the proportion of $\alpha$ crystals, the higher the proportion of milk fat that was liquid. A lower solid-to-liquid milk fat ratio may result in more milk fat being released from the cheese casein matrix (as a liquid) to form free oil. The higher free oil content of cheese made with the olein fraction may also be due to the lower energy required to melt the milk fat within the cheese, as evident from the smaller total energy under the DSC curve (Table 1).

There was no significant effect of the proportion of homogenized milk used on any of the melting properties of the milk fat in the Mozzarella cheese measured (Table

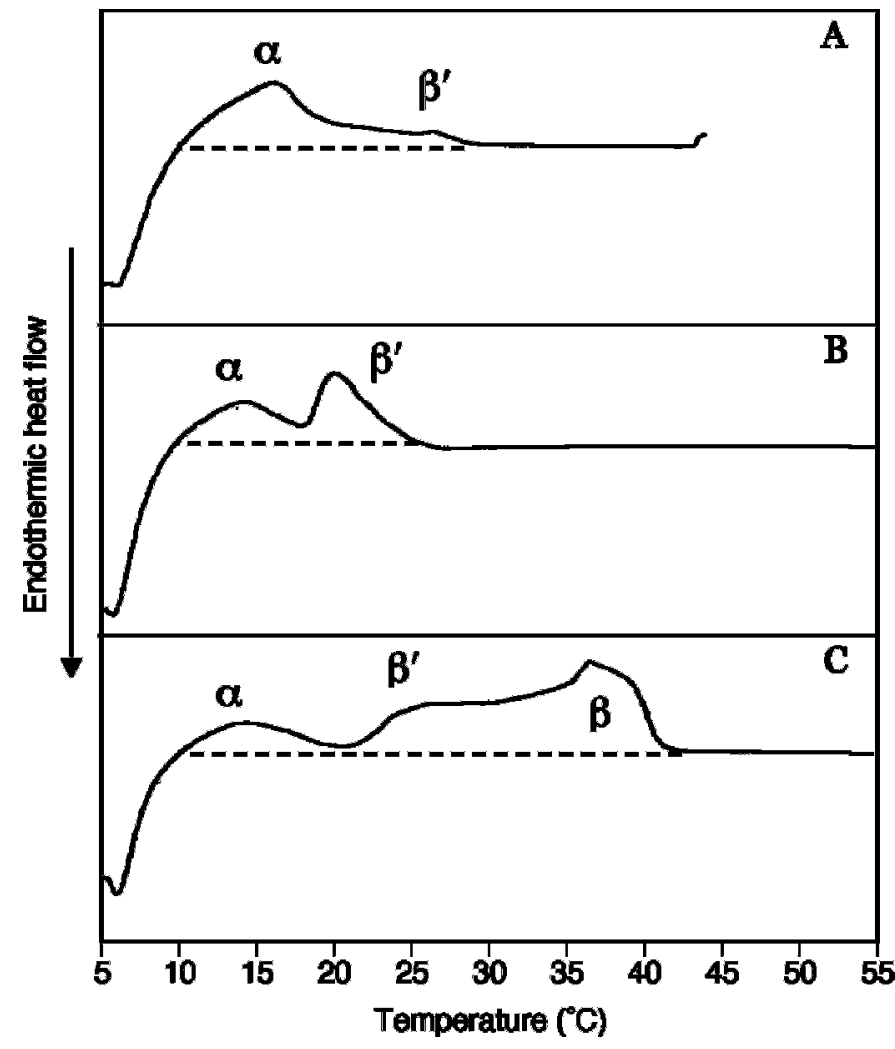

Figure 1. Polymorphic structure of milk fat in Mozzarella cheese made with olein low melting point milk fat fraction (A), anhydrous milk fat (B), and stearin high melting point milk fat fraction (C) as measured by differential scanning calorimetry. Crystals that melt below $20^{\circ} \mathrm{C}$ were designated $\alpha$, between 20 and $30^{\circ} \mathrm{C}$ as $\beta^{\prime}$, and above $30^{\circ} \mathrm{C}$ as $\beta$. The area above the dashed line was used to calculate relative proportions of each crystal type (Tables 1 and 2).

2). These results indicate that the formation of a new fat globule surface due to homogenization of the cheese milk did not impact the crystallization of the milk fat globules during cooling of the Mozzarella cheese.

\section{Milk Fat Globule Microstructure of Mozzarella Cheese}

Homogenization reduced the cross-sectional area of fat globules from 23.3 to $8.8 \mu \mathrm{m}^{2}(P<0.001)$ and the diameter of the milk fat globule from 4.9 to $3.9 \mu \mathrm{m}(P<$ $0.05)$. The decrease in fat globule size was concomitant with a decrease in free oil formation. It is not certain whether the reduction in free oil is caused by a more cohesive fat globule membrane, or a smaller sized globule that is less likely to rupture due to a higher Laplace pressure, which is the pressure difference across the curved membrane surface.

The CLSM micrographs show that milk fat appears to exist in two distinct states: a smaller, highly emulsified globule imbedded in the protein matrix, and larger pools 


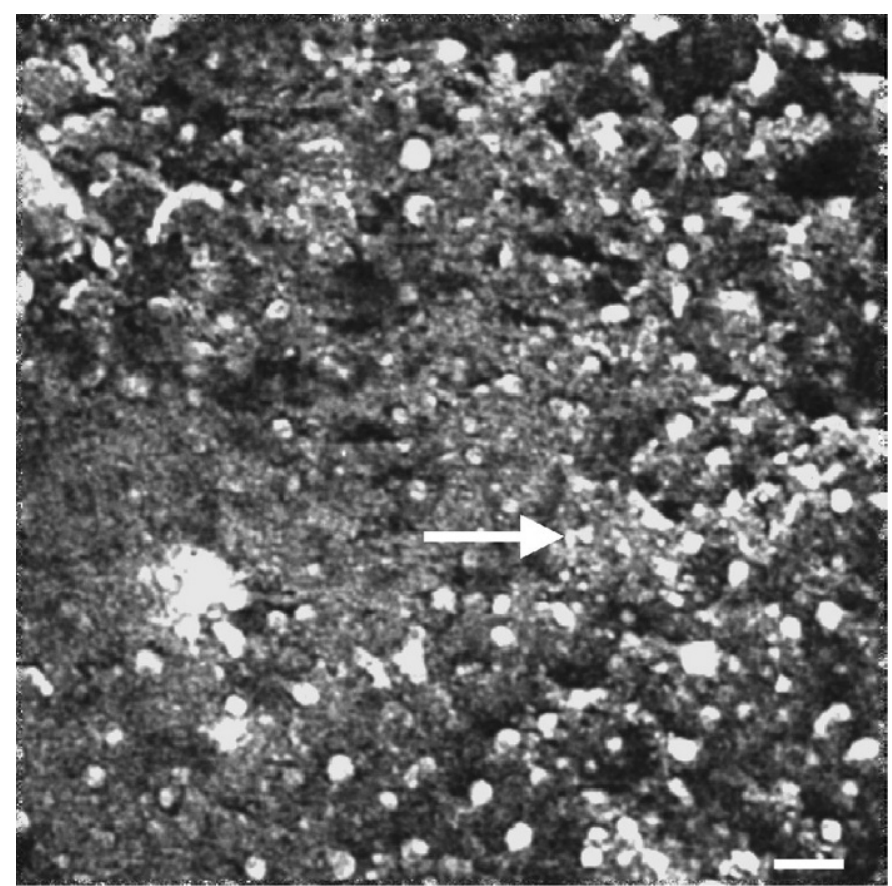

Figure 2. Confocal micrograph of Mozzarella cheese made with homogenized milk. Small highly emulsified fat globule in protein matrix indicated by arrow. Fat is shown as a lighter shade of gray. Scale bar $=10 \mu \mathrm{m}$.

of fat within voids in the protein matrix (Figures 2, 3, and 4). An increase in the degree of elongation of fat globules is believed to be an indicator of fat globule distortion in Cheddar cheese (Everett and Olson, 2003). The elongation factor of the fat globules made with fully or partly homogenized milk was not significantly different from the cheese made with milk that was not homogenized. Homogenization would be expected to produce more spherical globules with lower values for the elongation factor. The method of measuring fat globule distortion in this study was evidently not sensitive enough to pick up the observed differences in fat globule structure observed in Figures 2, 3, and 4.

There was no significant effect of the milk fat fraction on the microstructure of milk fat globules in Mozzarella cheese (Table 1). Therefore, the increase in free oil and decrease in apparent viscosity observed in cheese made with the lower melting point milk fat fraction can be attributed to an increase in proportion of low melting point $\alpha$ crystals rather than to changes in the milk fat globule microstructure. This was at least the case with fat globules partially coated with casein; however, the conclusion cannot yet be drawn for cheese containing fat globules coated only with the native milk fat globule membrane.

An increase in the solid-to-liquid milk fat ratio was shown to reduce free oil formation in Mozzarella cheese.

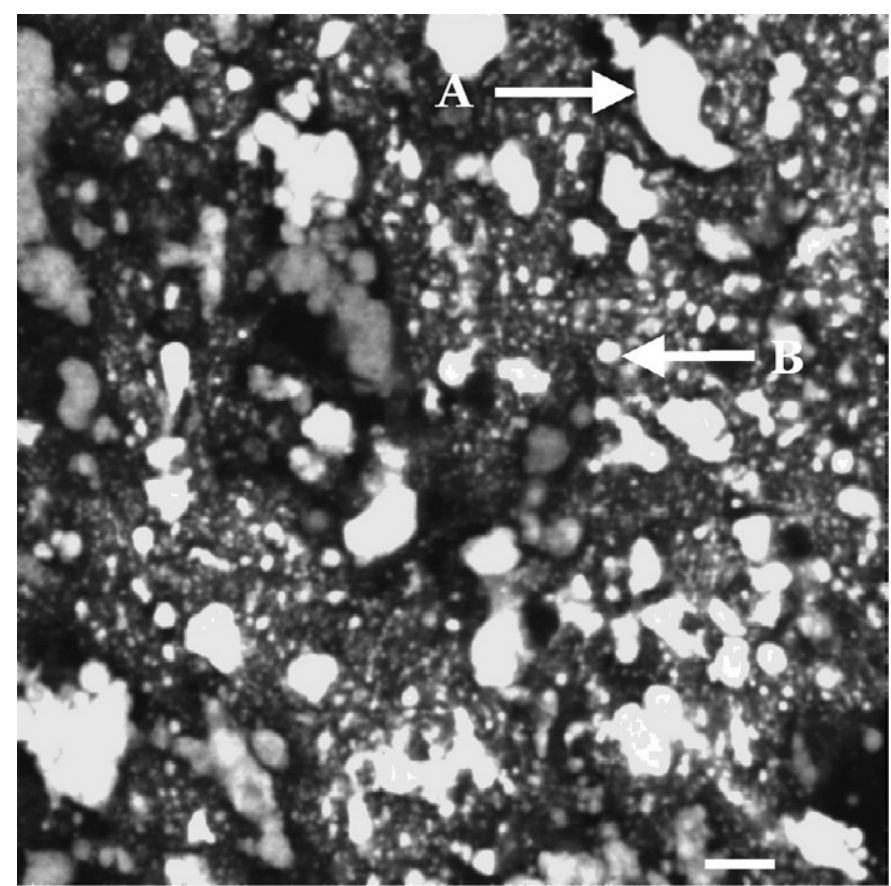

Figure 3. Confocal laser scanning micrograph of Mozzarella cheese made with 1:1 mixture of homogenized and nonhomogenized milk. Large fat pool indicated by arrow (A), small highly emulsified fat globule in protein matrix by arrow (B). Fat is shown as a lighter shade of gray. Scale bar $=10 \mu \mathrm{m}$.

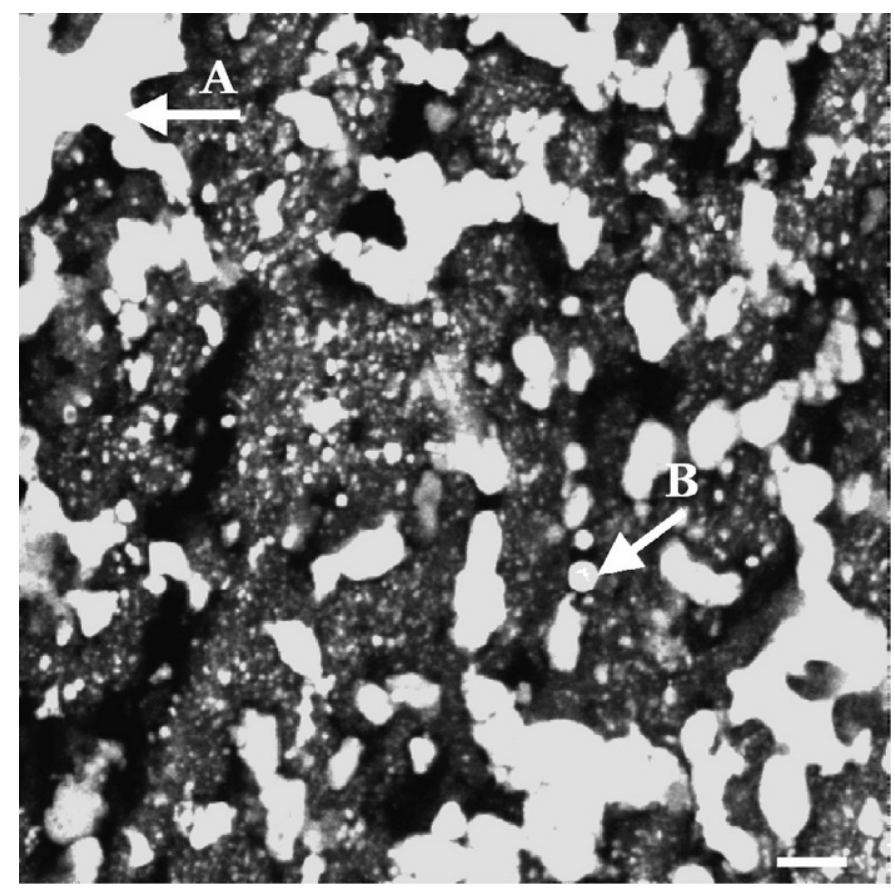

Figure 4. Confocal laser scanning micrograph of Mozzarella cheese made with nonhomogenized milk. Large fat pool indicated by arrow (A), small highly emulsified fat globule in protein matrix by arrow (B). Fat is shown as a lighter shade of gray. Scale bar $=10 \mu \mathrm{m}$. 
Given the large seasonal variation in melting properties of milk fat (Versteeg et al., 1994), this factor should be considered if tight control of free oil formation in Mozzarella cheese is necessary.

Partial homogenization of cheese milk was shown to decrease free oil formation. However, homogenization of cheese milk may also result in an increased apparent viscosity, which may not be desirable. Using homogenization as a mechanism for controlling free oil will require a systematic evaluation of homogenization pressures and temperatures so that other functional properties (such as an increase in moisture with increasing homogenization pressure) are not compromised to achieve the desired free oil content.

\section{CONCLUSIONS}

Milk fat exists in cheese in two distinct forms in Mozzarella cheese: small, highly emulsified globules, and larger pools of fat contained within the serum phase in the protein matrix. Globules containing the higher melting point fat fraction increased the viscosity of the melted cheese, presumably by a mechanism of partial destabilization and leaking of oil into the protein matrix. Homogenization of cheese milk yielded smaller globules partially coated with casein that interacted with the protein matrix in the cheese and were less likely to contribute to free oil formation. This cheese also had a higher viscosity as the globules were participating in, and strengthening the cheese casein matrix. Homogenization of cheese milk did not impact the crystallization of fat in the cheese. The melting point profile of the fat did not impact the size and shape of fat globules in the cheese. For the case of homogenized globules partially coated with casein, the increase in free oil for cheese containing a lower melting point fraction of fat was due to the ability of this fat to leak out of the protein matrix, rather than any putative differences in fat globule microstructure.

\section{ACKNOWLEDGMENTS}

This research was funded by a grant from the Dairy Research and Development Corporation, Melbourne, Australia. The authors acknowledge the assistance of Jeff Mayes from Food Science Australia in manufacturing cheese.

\section{REFERENCES}

Blonk, J. C. G., and H. van Aalst. 1993. Confocal scanning light microscopy in food research. Food Res. Int. 26:297-311.
Cano-Ruiz, M. E., and R. L. Richter. 1997. Effect of homogenization pressure on the milk fat globule membrane proteins. J. Dairy Sci. 80:2732-2739.

Everett, D. W., and N. F. Olson. 2003. Free oil and rheology of Cheddar cheese containing fat globules stabilized with different proteins. J. Dairy Sci. 86:755-763.

Guinee, T. P., M. A. E. Auty, and C. Mullins. 1999. Observations on the microstructure and heat-induced changes in the viscoelasticity of commercial cheese. Aust. J. Dairy Technol. 54:84-89.

International Dairy Federation. 1993. Determination of nitrogen content. Rep. No. 20B:1993, IDF, Brussels, Belgium.

International Dairy Federation. 1996. Determination of fat content. Rose-Gottlieb Gravimetric method. Rep. No. 1D:1996, IDF, Brussels, Belgium.

Kindstedt, P. S., and J. K. Rippe. 1990. Rapid quantitative test for free oil (oiling off) in melted Mozzarella cheese. J. Dairy Sci. 73:867-873.

Kindstedt, P. S., and L. J. Kiely. 1992. Revised protocol for the analysis of melting properties of Mozzarella cheese by helical viscometry. J. Dairy Sci. 75:676-682.

Lelievre, J., R. R. Shaker, and M. W. Taylor. 1990. The role of homogenization in the manufacture of Halloumi and Mozzarella cheese from recombined milk. J. Soc. Dairy Technol. 43:21-24.

McMahon, D. J., R. L. Fife, and C. J. Oberg. 1999. Water partitioning in Mozzarella cheese and its relationship to cheese meltability. J. Dairy Sci. 82:1361-1369.

Metzger, L. E., and V. V. Mistry. 1995. A new approach using homogenization of cream in the manufacture of reduced fat Cheddar cheese. 2. Microstructure, fat globule distribution, and free oil. J. Dairy Sci. 78:1883-1895.

Oberg, C. J., W. R. McManus, and D. J. McMahon. 1993. Microstructure of Mozzarella cheese during manufacture. Food Struct. 12:251258.

Park, J., J. R. Rosenau, and M. Peleg. 1984. Comparison of four procedures of cheese meltability evaluation. J. Food Sci. 49:1158-1162.

Poduval, V. S., and V. V. Mistry. 1999. Manufacture of reduced fat Mozzarella cheese using ultrafiltered sweet buttermilk and homogenized cream. J. Dairy Sci. 82:1-9.

Rowney, M. K., P. Roupas, M. W. Hickey, and D. W. Everett. 2003. The effect of compression, stretching, and cooking temperature on free oil formation in Mozzarella curd. J. Dairy Sci. 86:449-456.

Rudan, M. A., D. M. Barbano, M. R. Guo, and P. S. Kindstedt. 1998. Effect of the modification of fat particle size by homogenization on composition, proteolysis, functionality, and appearance of reduced fat Mozzarella cheese. J. Dairy Sci. 81:2065-2076.

Sharma, S. K., and D. G. Dalgleish. 1993. Interactions between milk serum proteins and synthetic fat globule membrane during heating of homogenized whole milk. J. Agric. Food Chem. 41:1407-1412.

Tunick, M. H., J. J. Basch, B. E. Maleeff, J. F. Flanagan, and V. H. Holsinger. 1989. Characterization of natural and imitation Mozzarella cheeses by differential scanning calorimetry. J. Dairy Sci. 72:1976-1980.

Tunick, M. H. 1994. Effects of homogenization and proteolysis on free oil in Mozzarella cheese. J. Dairy Sci. 77:2487-2493.

Tunick, M. H., and E. L. Malin. 1997. Differential scanning calorimetry of water buffalo and cow milk fat in Mozzarella cheese. J. Am. Oil Chem. Soc. 74:1565-1568.

Versteeg, C., L. N. Thomas, Y. L. Yep, M. Papalois, and P. S. Dimick. 1994. New fractionated milk fat products. Aust. J. Dairy Technol. 49:57-61.

Walstra, P., and R. Jenness. 1984. Dairy Chemistry and Physics. John Wiley \& Sons, New York.

Watkinson, P., G. Boston, O. Campanella, C. Coker, K. Johnston, M. Luckman, and N. White. 1997. Rheological properties and maturation of New Zealand Cheddar cheese. Lait 77:109-120. 